\title{
Adaptation of the Global Physical Activity Questionnaire (GPAQ) into Turkish: A validation and reliability study
}

\author{
İlker Adıgüzel@, İsabel Raika Durusoy Onmuş®D, Aliye Mandıracıŏglu®, Zeliha Aslı Öcek \\ Department of Public Health, Ege University Faculty of Medicine, Izmir, Turkey
}

Received: April 10, 2019 Accepted: March 08, 2020 Published online: May 25, 2021

\begin{abstract}
Objectives: The aim of this study was to adapt the World Health Organization's (WHO) Global Physical Activity Questionnaire (GPAQ) into Turkish and evaluate its reliability and validity among Bornova Municipality employees.

Patients and methods: The questionnaire was given its final Turkish form after its translation by two independent translators, a consensus meeting with both translators and the revision of the back-translation. An expert panel was organized for face validity and expert opinions were collected for content validity. The data of the study were collected in Municipality of Bornova district, Izmir province of Turkey between August 2016 and November 2016. Test-retest was used for reliability, International Physical Activity Questionnaire (IPAQ) was used for concurrent validity, and a pedometer was used for criterion validity. Among a total of 2,137 workers, a sample size of 352 employees was determined using 33\% prevalence with 5\% error margin, $95 \%$ confidence interval, and $20 \%$ non-response rate. The participants were selected with systematic sampling and 287 (81.5\%) workers (183 males, 104 females; mean age: $38.9 \pm 8.5$ years; range, 22 to 63 years) participated in the study.

Results: Reliability coefficients were substantial, near perfect (Kappa 0.74-0.87, p<0.001; Spearman rho 0.77-0.91, p<0.001). A substantial, near perfect relationship was found between IPAQ and GPAQ $(r=0.79-0.94, p<0.001)$. For criterion validity, a fair relationship was found between the pedometer results and GPAQ $(\mathrm{r}=0.32, \mathrm{p}=0.001)$. As for discriminant validity, the participants with physically active jobs had higher levels of physical activity compared to others (median: 3,240, 960 metabolic equivalent [MET]-min/per week, $\mathrm{p}<0.001$ ). Those with an income below the poverty line had median 2,400 MET-min/week compared to 1,200 for participants above the poverty line ( $<<0.001$ ). A significant difference was found among different education duration of employment groups.

Conclusion: The Turkish version of GPAQ is reliable and valid. Further validity and reliability studies of the GPAQ among non-working groups such as housewives, students, and unemployed ones can be recommended. Based on these findings, the GPAQ can be used as a valid and reliable tool in the Turkish population.
\end{abstract}

Keywords: Activities of daily living, metabolic equivalent, sedentary behavior, surveys and questionnaires, validation study.

Rapid urbanization in developing countries has led to significant changes in health and has increased the burden of chronic illnesses. ${ }^{[1]}$ Physical activity is a major, independent, and commutable risk factor of chronic diseases. Physical activity has substantial effects that protect from cardiovascular disease, stroke, type II diabetes, colon cancer, breast cancer, ${ }^{[2]}$ psychological problems, ${ }^{[3]}$ injuries, falls, and obesity. ${ }^{[4]}$
Physical activity is an area of public health interest around the world. According to systematic reviews, low level of physical activity increases all-causes mortality. ${ }^{[5]}$ A meta-analysis including 80 studies with $1,338,143$ participants $(118,121$ deceased), a $65 \%$ increased risk of mortality was found $(95 \%$ confidence interval [CI], 0.60-0.71) while comparing the highest and lowest levels of physical activity. ${ }^{[5]}$

Corresponding author: İlker Adıgüzel, MD. Ege Üniversitesi Tıp Fakültesi Halk Sağlığı Anabilim Dalı, 35100 Bornova, İzmir, Türkiye.

$$
\text { e-mail: ilkerad@gmail.com }
$$


Moderate-intensity physical activity is defined as activities during which a person spends three to six times more calories (3-6 metabolic equivalent [MET]) compared to sitting and vigorous-intensity physical activity as activities during which a person spends more than six times more calories ( $>6 \mathrm{MET}$ ) compared to sitting. The World Health organization (WHO) recommends that adults aged 18 to 64 should engage in at least $150 \mathrm{~min}$ of moderate-intensity aerobic physical activity or $75 \mathrm{~min}$ of vigorous-intensity aerobic physical activity weekly to remain healthy and promote health. Each aerobic activity should last at least $10 \mathrm{~min} .{ }^{[6]}$

It is important to use a standard protocol in surveying the levels of physical activity in the society. Surveillance is necessary to intervene on risk factors. Questionnaires and objective tools (e.g., pedometers and accelerometers) are the methods used most commonly for the evaluation of the physical activity. Surveys are frequently used in wide-scale epidemiological studies as a method of measurement, as they are low-cost, are not interventional, and enable to reach a high number of participants. ${ }^{[7]}$ Additionally, pedometers and accelerometers used for objective measurement are inadequate in differentiating activities done in different areas (i.e., work, transit, and leisure activities).

The International Physical Activity Questionnaire (IPAQ) is a scale commonly used in evaluating physical activity. It has short and long forms (IPAQ short, IPAQ long). However, it has certain disadvantages. The short form does not question about areas of activity such as work, transit, and leisure activities. The long form is, on the other hand, not suitable for community screening due to its length. Also, only the previous week is evaluated in the IPAQ, bringing a limitation on seasonality, and the representativeness of the past week during periods such as vacation and illness. The Global Physical Activity Questionnaire (GPAQ) was developed by the WHO to overcome these three disadvantages. ${ }^{[8]}$

The WHO recommends the STEPwise approach to Surveillance (STEPS) to identify chronic disease risks. The GPAQ is a component of STEPS. ${ }^{[2]}$ The STEPS comprises 10 sections, including demographic information, use of tobacco products, use of alcohol, diet, physical activity, history of hypertension, history of diabetes, history of high total cholesterol, history of cardiovascular disease, and a scan for cervical cancer for women.

The GPAQ individually asks about the places where physical activity is done (activity at work, travel to and from places, and recreational activities).
It comprises 16 questions. Vigorous and moderateintensity physical activities are described and their durations are asked in the workplace and leisure activities sections, and moderate-intensity physical activity (walking, bicycling) is questioned in the travel to and from places section. There is an additional question for the duration of the sedentary period..$^{[9]}$

The MET is defined as the metabolic speed in a person at rest. A MET is defined as the energy spent while sitting in a relaxed manner and is equivalent to $1 \mathrm{kcal} / \mathrm{kg} / \mathrm{h}$ caloric expenditure. The GPAQ measures how many MET-min of physical activity is engaged during a typical week. The MET-min per week obtained from the GPAQ is a scale-type variable. Moderateintensity physical activity corresponds to $4 \mathrm{MET} / \mathrm{min}$, and vigorous-intensity physical activity corresponds to $8 \mathrm{MET} / \mathrm{min} .{ }^{[6]}$ During the calculation of weekly total MET-min, the durations of each type of physical activity are multiplied by these coefficients.

In the present study, we aimed to adapt the GPAQ into Turkish and to evaluate its reliability and validity among employees of Bornova Municipality.

\section{PATIENTS AND METHODS}

This methodological study was conducted at Department of Public Health, Ege University Faculty of Medicine between August 2016 and November 2016. A total of 2,137 individuals worked in Municipality of Bornova district, Izmir province of Turkey. The reason for choosing municipal employees was to reach a heterogenous group in terms of socioeconomic level and physical activity. The frequency of physical activity in Turkey was found to be $33 \%$. ${ }^{[10]}$ The size of the smallest sample necessary for the study was determined to be 352 employees, assuming a 33\% prevalence, 5\% error margin, 95\% CI, and 20\% non-response rate. The sampling list was taken from the Bornova Municipality Human Resources Department, and 352 employees were systematically selected from the 2,137 employees. Among the target group, 287 employees (183 males, 104 females; mean age: $38.9 \pm 8.5$ years; range, 22 to 63 years) were participated in the study. Sixteen employees declined to participate in the research $(n=6$ due to intensity of work, and $n=10$ not giving consent). In addition, 49 employees could not be reached, despite being contacted twice. The response rate was $81.53 \%$.

\section{Criterion validity and sample size for test-retest}

The sample-size calculation for criterion validity was done with the $G^{*}$ Power version 3.1.9.2 software (Heinrich-Heine-Universität Düsseldorf, Düsseldorf, 
Germany). The sample size was calculated as 129 with a correlation coefficient of $0.31^{[9]}$ calculated with a pedometer in the GPAQ reliability and validity study conducted in nine countries (Bangladesh, Brazil, China [Shanghai, Taiwan], Indonesia, Ethiopia, South Africa, India, Japan, and Portugal). A pedometer was used for criterion validity and was administered to the first 112 employees who agreed to participate. The retest was applied to the same group one week later, when pedometers were returned. The acceptance rate was $86.82 \%$.

\section{Collection of data}

The data were gathered between August 17, 2016 and November 4, 2016. The questionnaire was filled out face-to-face with 287 employees at relevant Izmir Bornova Municipality workplaces. Employees who could not be reached on the first visit were visited a second time. Training was provided about how to use a pedometer to the 112 employees who first agreed to use pedometers for a week. Fifteen pedometers were used alternately throughout the data collection period. A sportive brand digital pedometer was used. The participants were told that they must attach the pedometers in an upright manner to their waists, that the pedometers must not touch water, that they must reset them when they wake up in the morning, and that they must note the number of steps when they go to bed each night throughout one-week period. The pedometer data were obtained at the end of one week, and the questionnaire was administered for the retest.

\section{Reliability and validity of the GPAQ}

The stages of reliability and validity included, in order, in the form of translation, expert panel (face validity), expert views (content validity), pilot study, retest, concurrent validity, criterion validity, and discriminant validity.

\section{Translation steps}

Two academicians, one a sports physician with an advance knowledge of the English language and the other a public health expert very fluent in English and independent of the research, translated the survey from English into Turkish. A panel was held with these experts and the researcher, and advisory faculty member. A third version of translation provided by the WHO Turkey Office was also evaluated during this meeting. The questions, examples of physical activity in the text, and sample cards providing visuals were reviewed and a joint Turkish form was created.
The created Turkish survey was translated back to English by two experts, one independent translator whose native language is English and a faculty member at a Foreign Languages Vocational School whose native language is Turkish. The translated English version was compared to the original version and the necessary changes were made.

\section{Expert panel (face validity)}

An expert panel was held with a faculty member from the Department of Public Health, a faculty member from the Department of Sports Medicine, a faculty member from the Faculty of Sports Sciences, and a physical therapist working at the university hospital. The questionnaire was reevaluated for intelligibility and its ability to measure physical activity. Corrections were made based on the recommendations of the experts.

\section{Expert views (content validity)}

Views were obtained from a total of 10 experts, including a faculty member at the Department of Sports Medicine, two physical therapists working at the university hospital, a faculty member from the Faculty of Sports Sciences, three faculty members from the Department of Public Health, two pilates instructors, and a dietician, through Google Forms. For each question, a response of "very suitable, quite suitable but small changes are necessary, the item must be changed in a suitable manner, not suitable" was taken. For each question, the answers of "very suitable" and "suitable but small changes are necessary" were collected and divided into the total number of experts. The cutoff of content validity was determined as a question remaining under $80 \%$, and changes were made in one question in accordance with the recommendations.

\section{Pilot study}

A pilot study was conducted with 12 municipal employees who were not selected for the sampling with the final state of the questionnaire (Appendix 1). "Cleaning work" was added as an example in this phase because of the feedback taken at the end of the pilot study and unpaid work was included in examples of moderate-intensity activity. This addition was considered necessary to be able to evaluate unpaid cleaning work at home.

\section{Data analysis and evaluation techniques}

The quality of the data was checked through a comparison of the data entered with the questionnaires in a $10 \%$ random sample from the database and checking the minimum and maximum values of each 
variable overall. The scale-type data were presented in mean \pm standard deviation (SD) and range (min-max) values.

The correlation coefficients were evaluated according to the following classification: ${ }^{[9]}$

- $0-0.20=$ poor

- $\quad 0.21-0.40=$ fair

- $\quad 0.41-0.60=$ moderate/acceptable

- $\quad 0.61-0.80=$ substantial

- $\quad 0.81-1.00=$ near perfect

\section{Categorical data acquired in the GPAQ}

Two questions were asked, in the form of "Yes/No", for vigorous- and moderate-intensity activities conducted in the GPAQ. Those who responded "No" to both type of activities at the workplace were accepted as "sedentary at work".

Two questions were asked, in the form of "Yes/No", for vigorous and moderate-intensity activities in leisure activities. Those who responded "No" to the both questions were accepted as "sedentary in leisure activities". These data were presented in descriptive number and percentage.

\section{Physical activity score calculation}

According to the GPAQ analysis guidebook, a night's sleep was accepted to last an average of $8 \mathrm{~h}$, and that the maximum period of time during which a person could engage in physical activity is $16 \mathrm{~h}$ daily. The lengths of time that exceeded $16 \mathrm{~h}$ were not taken into account. In this study, none of the participants reported daily physical activity exceeding $16 \mathrm{~h}$.

Total weekly MET-min: (Minutes engaged in moderate-intensity activity each week $\times 4 \mathrm{MET})+$ (Minutes engaged in vigorous-intensity activity each week $\times 8$ MET)

\section{Example:}

If one person walks $3 \mathrm{~h}$ and plays $1 \mathrm{~h}$ of basketball a week:

$180 \min \times 4+60 \min \times 8=1200$ MET-min is calculated.

Levels below 600 MET-min weekly were accepted as physically inactive. ${ }^{[1]}$

\section{Reliability evaluations}

Kappa analysis was done for categorical variables to evaluate the test-retest reliability. The acceptance percentages for those who responded "Yes" in both tests were calculated. Spearman correlation analysis was conducted for scale-type data, as they did not show normal distribution.

\section{Validity evaluations}

The scale was not suitable for factor analysis, since different categories of physical activity (leisure, work, transport) were measured in MET-min.

\section{Concurrent validity}

The IPAQ was used to evaluate concurrent validity in the other reliability and validity studies. ${ }^{[9]}$ It is a questionnaire developed to measure physical activity and it was previously tested. The Turkish reliability and validity study was conducted by Öztürk. ${ }^{[12]}$ The variables that could be compared in GPAQ and IPAQ were similar. They were evaluated with the Spearman correlation analysis, as the total physical activity variables did not follow normal distribution.

\section{Criterion validity}

In similar studies, a pedometer or accelerometer were used for the objective measurement of physical activity. Respondents tended to exaggerate the intensity and/or duration of activity while completing the questionnaire. Such objective methods may overcome the limitations of the questionnaires. In this study, a pedometer was used for criterion validity. The total duration of physical activity acquired from the GPAQ and the daily number of steps acquired from the pedometer were compared using the Spearman correlation analysis.

\section{Discriminant validity}

For discriminant validity, to find out whether the questionnaire could differentiate physical activity levels of different groups, a sociodemographic form containing following variables was used: Age, sex, education level, marital status, number of children, duration of work in years at the municipality, job in the municipality, total monthly working time (h), chronic diseases diagnoses, drugs used continuously, tobacco use history, hobby history, licensed sports history, body mass index (BMI), per capita income. Our hypothesis was that GPAQ could differentiate between different groups.

\section{Ethical issues}

Permission from the WHO for the adaptation of the scale

The WHO Noncommunicable Diseases and Mental Health Cluster was applied via email. The surveillance 
department was, then, contacted and the permission was obtained. The feasibility of the conduction of the research on municipal employees was consulted, and an approval was obtained. Support was obtained in this process from the WHO Turkey Office, and a version of the GPAQ translated into Turkish and for which no reliability or validity research was performed was acquired. This text was also considered during the translation stage.

\section{Ethics approval}

Ethics approval was obtained from Ege University, Faculty of Medicine, Clinical Research Ethics Council (No. 16-5/18; Date: 02.06.2016). The municipality was contacted officially and permission was obtained for the study. The municipal employees agreed to participate in the study, filling out the informed consent form.

\section{RESULTS}

\section{Descriptive characteristics of the research group}

This study included a total of 287 employees working at Izmir Bornova Municipality. The sociodemographic characteristics of the participants are presented in Table 1. The mean income per capita of the employees was $1,676.43 \pm 1,078.16$ TRY (range, 216.67 to $5,500 \mathrm{TL}$ ).

The mean BMI of the employees was $25.8 \pm 4.2$ (range, 16.3 to 50.8$) \mathrm{kg} / \mathrm{m}^{2}$. The mean duration of working at the municipality was $9.5 \pm 7.3$ (range, 1 to 34 ) years. The mean total working h per month for the employees was $171.7 \pm 10.9$ (range, 160 to 200) h. Corresponding categorical data are shown in Table 1 along with the categorical responses to the activity types questioned in GPAQ.

The physical activity levels of the employees in MET-min are summarized in Table 2. The levels of physical activity for $80.5 \%$ of the employees were over the WHO-recommended weekly 600 MET-mins.

\section{Reliability analyses \\ Reliability analysis for the presence of physical activity}

The test-retest reliability for the categorical variables of GPAQ is shown in Table 3. The kappa statistics for all the categorical variables ranged between 0.74 (substantial relationship for vigorous-intensity activity at work) and 0.87 (near perfect relationship for being sedentary in

\begin{tabular}{|c|c|c|}
\hline \multicolumn{3}{|c|}{$\begin{array}{l}\text { TABLE } 1 \\
\text { Distribution of employees by sociodemographic, health, } \\
\text { municipal work characteristics and physical activity status }\end{array}$} \\
\hline Features & $\mathrm{n}$ & $\%$ \\
\hline \multicolumn{3}{|l|}{ Sex } \\
\hline Female & 104 & 36.2 \\
\hline \multicolumn{3}{|l|}{ Age group } \\
\hline 18-34 years & 95 & 33.1 \\
\hline $35-44$ years & 122 & 42.5 \\
\hline $45-63$ years & 70 & 24.4 \\
\hline \multicolumn{3}{|l|}{ Education level group } \\
\hline Secondary school and below & 69 & 24.0 \\
\hline High school & 92 & 32.1 \\
\hline University and above & 126 & 43.9 \\
\hline \multicolumn{3}{|l|}{ Marital status } \\
\hline Married & 196 & 68.3 \\
\hline \multicolumn{3}{|l|}{ Number of children } \\
\hline No child & 102 & 35.5 \\
\hline One child & 90 & 31.4 \\
\hline Two children and above & 95 & 33.1 \\
\hline Per capita income at or below the poverty line & 107 & 39.5 \\
\hline Having a chronic disease & 104 & 36.2 \\
\hline Continuously used drug history & 79 & 27.5 \\
\hline \multicolumn{3}{|l|}{ Smoking history } \\
\hline Smoking & 140 & 48.8 \\
\hline Quit & 36 & 12.5 \\
\hline Never smoked & 111 & 38.7 \\
\hline Participants having a hobby & 167 & 58.2 \\
\hline Participants with licensed sports history & 74 & 25.8 \\
\hline \multicolumn{3}{|l|}{ Body mass index } \\
\hline Underweight $<18.5$ & 5 & 1.7 \\
\hline Normal 18.5-24.9 & 122 & 42.5 \\
\hline Overweight 25-29.9 & 123 & 42.9 \\
\hline Obese $\geq 30$ & 37 & 12.9 \\
\hline \multicolumn{3}{|l|}{ Duration of work at the municipality } \\
\hline $1-5$ years & 105 & 36.6 \\
\hline $6-10$ years & 92 & 32.1 \\
\hline 11 years and above & 90 & 31.4 \\
\hline Working 160 hours a month & 127 & 44.3 \\
\hline Physically active work & 90 & 31.4 \\
\hline \multicolumn{3}{|l|}{ GPAQ categorical questions } \\
\hline Vigorous-intensity activity at work & 15 & 5.2 \\
\hline Moderate-intensity activity at work & 166 & 57.8 \\
\hline Sedentary at work & 117 & 40.8 \\
\hline Walking or cycling in transportation & 177 & 61.7 \\
\hline Vigorous-intensity activity in leisure time & 52 & 18.1 \\
\hline Moderate-intensity activity in leisure time & 138 & 48.1 \\
\hline Sedentary in leisure time & 126 & 43.9 \\
\hline
\end{tabular}

leisure). The acceptance rate ranged between $92 \%$ (for sedentary and moderate-intensity activity at work) and $98 \%$ (for vigorous-intensity activity at work). 


\begin{tabular}{|lccc|}
\multicolumn{5}{c}{ TABLE 2 } & & \\
Physical activity & (MET-min) characteristics of employees & \\
\hline Physical activity status & Mean \pm SD & Median & Min-Max \\
\hline Vigorous-intensity activity at work & $74.70 \pm 860.94$ & 0 & $0-14,400$ \\
Moderate-intensity activity at work & $1,220.91 \pm 2,091.77$ & 320 & $0-11,520$ \\
Total activity at work & $1,295.61 \pm 2,322.31$ & 480 & $0-18,720$ \\
Activity at transportation & $389.48 \pm 451.03$ & 400 & $0-2,520$ \\
Vigorous-intensity activity in leisure time & $180.07 \pm 634.81$ & 0 & $0-7,680$ \\
Moderate-intensity activity in leisure time & $312.82 \pm 593.86$ & 0 & $0-4,200$ \\
Total activity in leisure time & $492.89 \pm 958.58$ & 240 & $0-11,520$ \\
Total vigorous-intensity activity & $254.77 \pm 1,061.90$ & 0 & $0-14,400$ \\
Total moderate-intensity activity & $1,923.21 \pm 2,173.99$ & 1,080 & $0-12,720$ \\
Total physical activity & $2,177.98 \pm 2,483.00$ & 1,360 & $0-19,680$ \\
\hline SD: Standard deviation; Min: Minimum; Max: Maximum. & & & \\
\hline
\end{tabular}

Reliability analysis for the level of physical activity in MET-min

The test-retest reliability for the measurementtype variables of the GPAQ is shown in Table 4 . The Spearman rho correlation coefficients ranged between 0.77 (substantial relationship for vigorousintensity activity at work) and 0.91 (near perfect relationship for being sedentary during leisure).

\section{Concurrent validity analysis}

Concurrent validity correlation coefficient is shown in Table 5. The Spearman rho coefficient between the GPAQ and IPAQ ranges between 0.79 (substantial relationship for total moderate-intensity activity) and 0.85 (near perfect relationship for total vigorous-intensity activity). The highest correlation coefficient was observed for the sedentary period (0.94).

\section{Criterion validity analysis}

The correlation coefficient between the GPAQ score in MET-min and the average daily number of steps for criterion validity is shown in Table 5. The correlation coefficient between GPAQ and the pedometer for total physical activity is 0.32 (fair relationship). The correlation coefficient between the sedentary period (sitting, h) and GPAQ was 0.23 (fair relationship).

\section{Discriminant validity}

Education level, length of time spent working at the municipality, income per capita, and status of physical active work led to a statistically significant difference at the GPAQ MET-min level. There was no statistically significant difference in the mean MET-min physical activity levels of different sex and age group, marital status, number of children, total working hours of

\begin{tabular}{|lccc|}
\hline \multicolumn{4}{|c|}{ TABLE 3 } \\
\multicolumn{4}{|c|}{ Test-retest reliability for existence of physical activity } \\
\hline Activity location $(\mathrm{n}=112)$ & Kappa & Acceptance $(\%)$ & $p$ \\
\hline Activity at work & & & \\
Sedentary & 0.82 & 92.0 & $<0.001$ \\
Vigorous-intensity activity & 0.74 & 98.2 & $<0.001$ \\
Moderate-intensity activity & 0.83 & 92.0 & $<0.001$ \\
Transportation & & & \\
Walking or cycling & 0.84 & 92.9 & $<0.001$ \\
Activity in leisure time & & & \\
Sedentary & 0.87 & 93.8 & $<0.001$ \\
Vigorous-intensity activity & 0.86 & 96.4 & $<0.001$ \\
Moderate-intensity activity & 0.85 & 92.9 & $<0.001$ \\
\hline
\end{tabular}




\begin{tabular}{|lcc|}
\hline \multicolumn{3}{|c|}{ TABLE 4 } \\
Test-retest reliability for physical activity level (MET-min) \\
\hline Activity location (n=112) & Spearman's Rho & $p$ \\
\hline Activity at work & & \\
Sedentary & 0.77 & $<0.001$ \\
Vigorous-intensity activity & 0.90 & $<0.001$ \\
Moderate-intensity activity & 0.90 & $<0.001$ \\
Transportation & & \\
Walking or cycling & 0.88 & $<0.001$ \\
Activity in leisure time & & \\
Vigorous-intensity activity & 0.89 & $<0.001$ \\
Moderate-intensity activity & 0.91 & $<0.001$ \\
Total activity in leisure time & 0.90 & $<0.001$ \\
Total physical activity & 0.86 & $<0.001$ \\
\hline
\end{tabular}

worked monthly, medical history, history of prescribed medications, cigarette use, hobbies, certified sports, and BMI, categories (Table 6).

\section{DISCUSSION}

A substantial relationship was found in the test-retest reliability for the overall score and scores of the different domains of the Turkish GPAQ. A substantial relationship in the concurrent validity and a fair relationship in the criterion validity were also found. A substantial relationship in the existence of vigorous-intensity activity at work from the categorical variables was found in the test-retest reliability (0.74), and a near perfect relationship was found in the others $(0.82-0.87)$. Reliability might have been lower for vigorous-intensity activities, as fewer employees reported engagement in vigorous-intensity physical activity at work and these vigorous-intensity activities at work might vary from week to week. The high kappa values can be explained with the education levels of the municipal workers and their employment status being better than that of the general public and also employees doing routine and defined work. Lower kappa values ranging from 0.67 to 0.73 were reported in the GPAQ reliability and validity studies of nine countries, which could be linked to the fact that the research was conducted in nine different countries and the characteristics of physical activity could be different among the countries. While reviewing individual countries, the kappa values ranged between 0.34 and $1.00 .^{[9]}$

The physical activity kappa values ranged between 0.50 and 0.62 in a GPAQ reliability and

\begin{tabular}{|c|c|c|}
\hline \multicolumn{3}{|c|}{$\begin{array}{c}\text { TABLE } 5 \\
\text { Validity analyses as compared to IPAQ and pedometer }\end{array}$} \\
\hline \multicolumn{2}{|c|}{ Concurrent validity between GPAQ and IPAQ } & \multirow[b]{2}{*}{$p$} \\
\hline Activity location $(\mathrm{n}=287)$ & Spearman's Rho & \\
\hline Total vigorous-intensity activity & 0.85 & $<0.001$ \\
\hline Total moderate-intensity activity & 0.79 & $<0.001$ \\
\hline Total physical activity & 0.80 & $<0.001$ \\
\hline Sedentary duration & 0.94 & $<0.001$ \\
\hline \multicolumn{3}{|c|}{ Criterion validity between GPAQ and pedometer } \\
\hline Variable $(n=112)$ & Spearman's Rho & $p$ \\
\hline Total physical activity & 0.32 & 0.001 \\
\hline Sedentary duration & -0.23 & 0.012 \\
\hline
\end{tabular}

validity study conducted on individuals working and studying at the medical school of a university in France. ${ }^{[13]}$ The kappa value was found to be 0.33 in the section the interviewer administered in the reliability and validity study for the versions the participants and interviewer administered for the GPAQ administered to employees and students at a university in Singapore. ${ }^{[14]}$ The kappa values in these studies might have been lower compared to our study, as the levels of physical activity of the students and academics might vary.

A substantial relationship was found in the MET-min of vigorous-intensity activities (0.77) and a near perfect relationship was found for the other types of physical activities (0.88-0.91). The correlation coefficients might have been higher, since the educational level and employment status of the municipal workers were relatively higher than the public. The correlation coefficients ranged between 0.67 and 0.81 in the analysis in which data from nine countries were combined. While reviewing individual countries' results, the values for the correlation coefficients ranged between 0.40 and 1.00 for the measurement-type variables. ${ }^{[9]}$ The correlation coefficient range could be greater, as this research was conducted in many countries. The municipal workers in our study could be considered as having the same culture and they work at the same institution. Therefore, the correlation coefficients might be found to be higher and the range to be narrower.

The Spearman rho coefficients for the measurement-type variables vary between 0.52 and 0.89 in the French reliability and validity study 


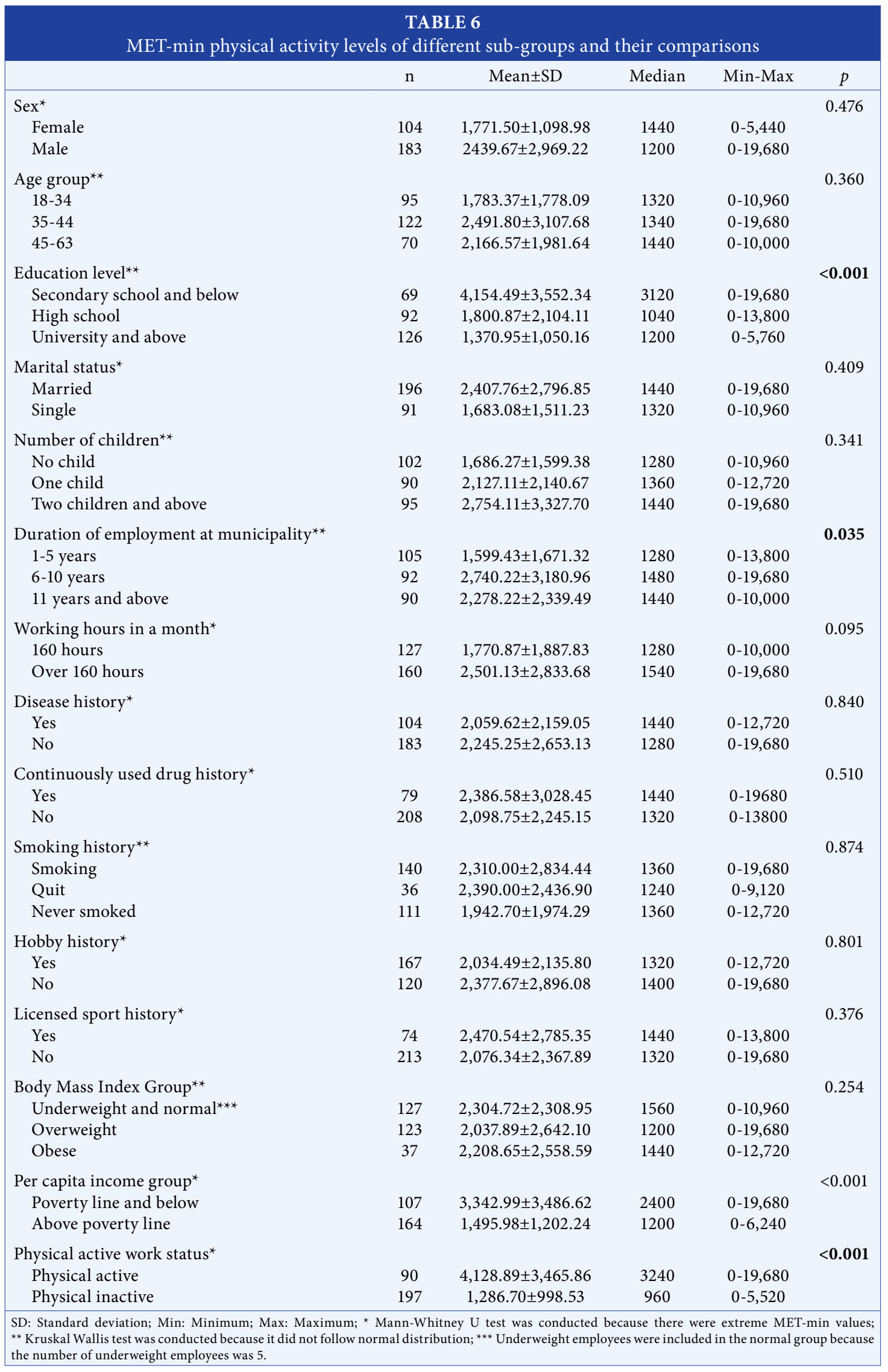


for GPAQ, conducted with 68 participants. ${ }^{[13]}$ The Spearman rho coefficients for the measurement-type variables vary between 0.52 and 0.82 in the section administered by the interviewer in the reliability and validity study in the versions implemented by the participant and interviewer for the GPAQ conducted with 56 participants. ${ }^{[14]}$ The reliability coefficients vary between 0.44 and 0.77 for the measurement-type data in the validity study for the GPAQ conducted in 62 Saudi males. ${ }^{[15]}$ The correlation values might be low due to the low number of participants.

The test-retest Spearman rho coefficients were 0.50-0.69 for the IPAQ short form in the IPAQ Turkish reliability and validity study conducted on university students. They ranged between 0.55 and 0.99 for the IPAQ long form. ${ }^{[12]}$ Although university students are more educated and younger, their correlation coefficients might have been lower than GPAQ, as the IPAQ asks specifically about the past week and as a person's level of physical activity can vary from week to week.

For concurrent validity, when the weekly MET-min values of IPAQ were compared with GPAQ, the correlation coefficients varied between 0.79 and 0.85 . In the nine-country study, the correlation coefficients were between 0.45 and 0.57 in the countries-combined analysis GPAQ. The correlation coefficients ranged between 0.29 and 0.92 for individual countries. ${ }^{[9]}$ The correlation coefficients might have a wider range due to the conduction of the research in many countries. The correlation coefficients might be found to be higher and the range to be narrower, as the municipal workers in our study are culturally more homogenous, they work at the same institution, and have a higher level of education, compared to the community.

The highest correlation coefficient between IPAQ and GPAQ was found for the sedentary period (0.94), since the question that asks about sedentary length in the IPAQ is the same as in the GPAQ. However, the correlation coefficient for the sedentary period was found to be 0.65 in the analysis combining nine countries' data. Among individual country results, the correlation coefficients ranged between 0.45 and 0.98 for sedentary duration. ${ }^{[9]}$ Our findings are consistent with this research.

The Spearman rho coefficients for the GPAQ ranged between 0.53 and 0.81 , compared to the IPAQ in the French reliability and validity study. ${ }^{[13]}$ The correlation coefficients might be low, as the number of participants was 92. The Spearman rho coefficients for the GPAQ ranged between 0.44-0.46, compared to the IPAQ in the reliability and validity study conducted on 43 nurses in Malaysia. ${ }^{[16]}$ The correlation coefficients might have emerged to be lower, as the number of participants was low, the working order of nurses might vary from week to week, and the IPAQ inquiries about the previous week, while the GPAQ asks about an average week.

The correlation between regarded total physical activity and daily average number of steps using a pedometer for criterion validity is at the level of a fair relationship $\left(r_{s}=0.32\right)$. The correlation coefficient for the pedometer was similarly 0.31 in the analysis of the data combined from nine countries for the GPAQ. For the analysis of each individual country, the correlation coefficients ranged between 0.23 and 0.35 for pedometer. ${ }^{[9]}$ The correlation coefficients might be low, as the pedometer was able to perceive the best walking and running motions, but was unable to perceive other types of physical activity.

A study researching the correlation between GPAQ and pedometers in desk employees in Thailand found no significant relationship between weekly MET-min and the pedometer (Spearman rho $=0.08$, $\mathrm{p}=0.15),{ }^{[17]}$ probably due to the fact that participants were a sedentary group. The Spearman rho coefficient between the daily average number of steps in the reliability and validity study conducted for the GPAQ in Malaysia and the weekly MET-min was 0.30 $(p=0.002) .{ }^{[16]}$ The findings are consistent with our research.

The Turkish version of the GPAQ, which is already in use in many countries by the WHO and which has fewer limitations, compared to the IPAQ, was adapted, evaluated in many different aspects, and found to be reliable and valid.

The GPAQ is a questionnaire comprising both categorical and measurement-type questions. Transit, leisure, and work activities are calculated as MET-min per week with counting- and measurement-type variables, and the total level of physical activity is determined from the type of MET-min per week with the total. Therefore, it was not possible to calculate the Cronbach alpha coefficient used in typical Likert scales. The scale was also not suitable for factor analysis due its nature explained. A receiver operating characteristic (ROC) curve was unable to be drawn, since there was no gold-standard method in evaluating physical activity in a Yes/No or adequate/inadequate dichotomous manner, and no cut-off point or, based 
on this, sensitivity and specificity could not be determined. This can be accepted as a limitation, as the accuracy of the given responses could not be certain. There are possibilities of the levels of physical activities between those who agreed and did not agree to participate being different, of potential incompetence in complying with the use of the pedometer, and of a possible motivational effect by the use of to engage in physical activity.

In conclusion, the results from the test-retest reliability for the GPAQ were good. The concurrent validity of the GPAQ was found to be good. Criterion validity was at an fair level. The GPAQ was able to differentiate statistically significantly between education level, duration of work at the municipality, income per capita, and status of physical active work in discriminant validity. An international questionnaire was adapted with this study to be used to measure physical activity in Turkey. Based on these findings, the Turkish version of the GPAQ is reliable and valid. Its recommendation and use by the WHO makes the questionnaire more important. Questioning about activities performed in various areas and an average week rather than the previous week makes the questionnaire superior compared to past questionnaires. The WHO's international use of the GPAQ to scan for risk around the world is an advantage for comparison between countries.

\section{Declaration of conflicting interests}

The authors declared no conflicts of interest with respect to the authorship and/or publication of this article.

\section{Funding}

The authors received no financial support for the research and/or authorship of this article.

\section{REFERENCES}

1. TUNSTAlL-PEDOE H. Preventing Chronic Diseases. A Vital Investment: WHO Global Report. Geneva: World Health Organization, 2005. pp 200. CHF 30.00. ISBN 924 1563001. International Journal of Epidemiology 2006;35:1107.

2. Bull F, Armstrong TP, Dixon T, Ham S, Neiman A, Pratt M. Physical Inactivity. In: Ezzati M, Lopez AD, Rodgers A, Murray CJL, editors. Comparative Quantification of Health Risks. Global \& Regional Burden of Disease Attributable to Selected Major Risk factors. Geneva: World Health Organization; 2004. p. 731-883.
3. Saxena S, Van Ommeren M, Tang KC, Armstrong TP. Mental health benefits of physical activity. Journal of Mental Health 2005;14:445-51.

4. Bauman AE. Updating the evidence that physical activity is good for health: an epidemiological review 2000-2003. J Sci Med Sport 2004;7(1 Suppl):6-19.

5. Samitz G, Egger M, Zwahlen M. Domains of physical activity and all-cause mortality: systematic review and doseresponse meta-analysis of cohort studies. Int J Epidemiol 2011;40:1382-400.

6. WHO. (2012). Global Physical Activity Questionnaire (GPAQ) Analysis Guide. Geneva: World Health Organization, 1-22. Available at: http://www.who.int/chp/ steps/resources/GPAQ_Analysis_Guide.pdf

7. Blair J, Czaja RF, B. E. (2014). Designing surveys: a guide to decisions and procedures (3rd Editio.). Thousand Oaks, CA: Sage Publications.

8. Armstrong T, Bull F. Development of the World Health Organization Global Physical Activity Questionnaire (GPAQ). Journal of Public Health 2006;14:66-70.

9. Bull FC, Maslin TS, Armstrong T. Global physical activity questionnaire (GPAQ): nine country reliability and validity study. J Phys Act Health 2009;6:790-804.

10. Sağlık Bakanlığı. Türkiye Beslenme ve Sağlık Araştırması 2010: Beslenme Durumu ve Alışkanlıklarının Değerlendirilmesi Sonuç Raporu; 2014.

11. WHO. Global recommendations on physical activity for health. Geneva: World Health Organization; 2010.

12. Öztürk M. Üniversitede eğitim-ögretim gören öğrencilerde uluslararası fiziksel aktivite anketinin geçerliligi ve güvenirliği ve fiziksel aktivite düzeylerinin belirlenmesi. Hacettepe Üniversitesi/Sağlık Bilimleri Enstitüsü; 2005.

13. Rivière F, Widad FZ, Speyer E, Erpelding ML, Escalon H, Vuillemin A. Reliability and validity of the French version of the global physical activity questionnaire. Journal of Sport and Health Science 2016;7:339-45.

14. Chu AH, Ng SH, Koh D, Müller-Riemenschneider F. Reliability and Validity of the Self- and InterviewerAdministered Versions of the Global Physical Activity Questionnaire (GPAQ). PLoS One 2015;10:e0136944.

15. Alkahtani SA. Convergent validity: agreement between accelerometry and the Global Physical Activity Questionnaire in college-age Saudi men. BMC Res Notes 2016;9:436.

16. Soo KL, Wan Abdul Manan WM, Wan Suriati WN. The Bahasa Melayu version of the Global Physical Activity Questionnaire: reliability and validity study in Malaysia. Asia Pac J Public Health 2015;27:NP184-93.

17. Sitthipornvorakul E, Janwantanakul P, van der Beek AJ. Correlation between pedometer and the Global Physical Activity Questionnaire on physical activity measurement in office workers. BMC Res Notes 2014;7:280. 


\section{Appendix-1}

Türkçe Küresel Fiziksel Aktivite Anketi (The Global Physical Activity Questionnaire; GPAQ)

\section{Fiziksel Aktivite}

Şimdi size sıradan bir haftada farklı tipte fiziksel aktiviteler yaparken (hareket ederken) harcadığınız zamanı soracağım. Lütfen bu sorulara kendinizin fiziksel olarak aktif bir insan olduğunu düşünmeseniz de yanıt verin.

Önce iş yaparken harcadığınız zamanı düşünün. İş olarak şunları düşünün: Yapmak zorunda olduğunuz ücretli ya da ücretsiz işler, ders çalışma/eğitim, ev işleri, gıda/ekin hasatı, beslenmek için balık tutma ya da ava çıkma, iş arama vb. [Gerekirse başka örnekler ekleyiniz]. Aşağıdaki soruları yanıtlarken "yüksek şiddetli aktiviteler" ağır fiziksel çaba gerektiren, solunum veya kalp atım hızında büyük artışlara yol açan aktivitelerdir; "orta şiddetli aktiviteler" orta derecede fiziksel çaba gerektiren, solunum veya kalp atım hızında küçük artışlara yol açan aktivitelerdir.

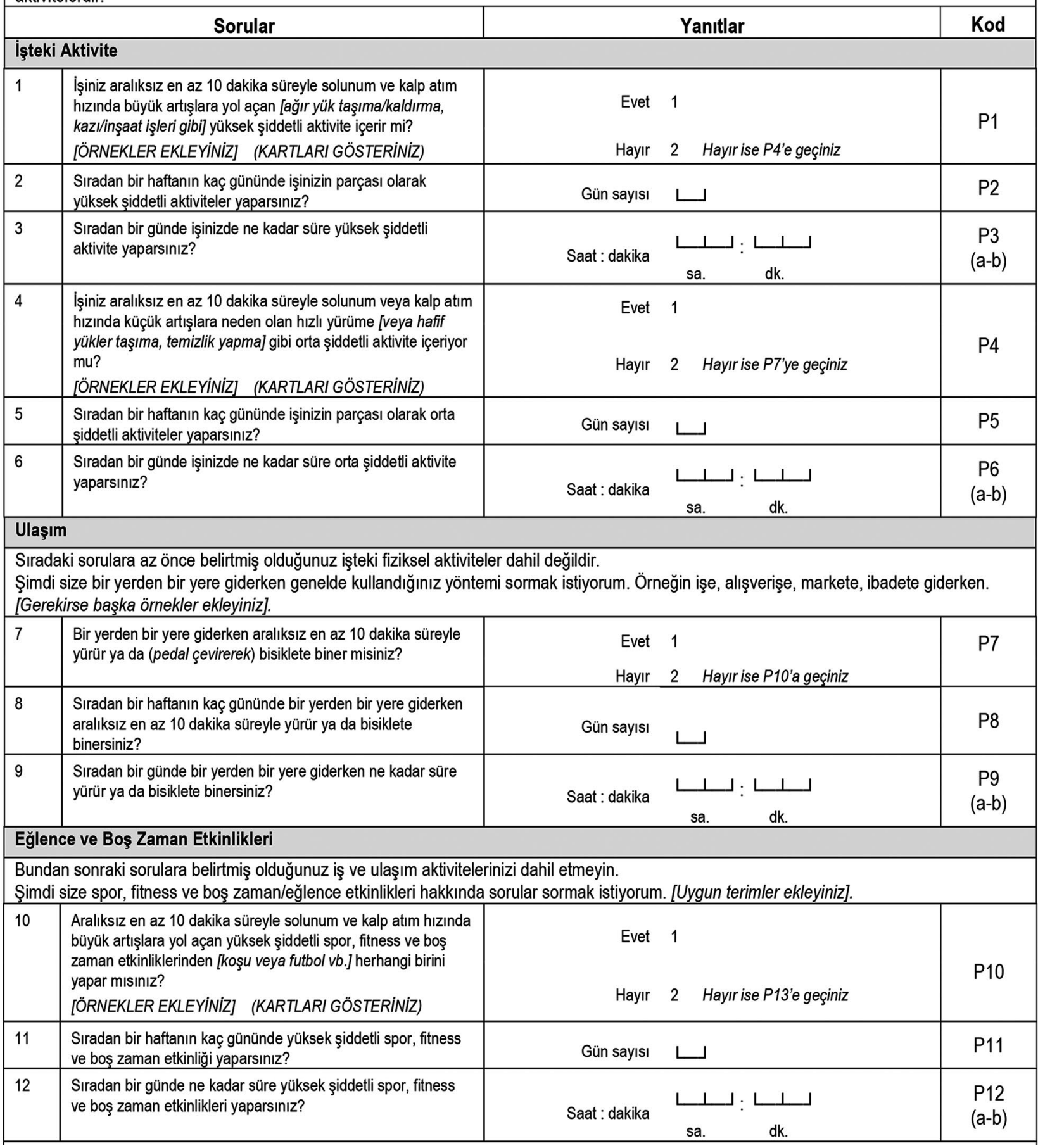




\section{Appendix-1}

Devamı (Continued)

\begin{tabular}{|c|c|c|c|}
\hline \multicolumn{4}{|c|}{ Fiziksel Aktivite (Eğlence ve Boş Zaman Etkinlikleri) } \\
\hline \multicolumn{2}{|r|}{ Sorular } & Yanitlar & Kod \\
\hline 13 & $\begin{array}{l}\text { Aralıksız en az } 10 \text { dakika süreyle solunum ve kalp atım } \\
\text { hızında küçük artışlara neden olan hızlı yürüyüşs [bisiklete } \\
\text { binme, yüzme, voleybol] gibi orta şiddetli spor, fitness ve boş } \\
\text { zaman etkinliklerinden herhangi birini yapar mısınız? } \\
\text { [ÖRNEKLER EKLEYINIZ] (KARTLARI GÖSTERINIZ) }\end{array}$ & $\begin{array}{l}\text { Evet } 1 \\
\text { Hayır } 2 \text { Hayır ise P16'ya geçiniz }\end{array}$ & P13 \\
\hline 14 & $\begin{array}{l}\text { Sıradan bir haftanın kaç gününde orta şiddetli spor, fitness ve } \\
\text { boş zaman etkinlikleri yaparsınız? }\end{array}$ & Gün sayısı & P14 \\
\hline 15 & $\begin{array}{l}\text { Sıradan bir günde ne kadar süre orta şiddetli spor, fitness ve } \\
\text { boş zaman etkinlikleri yaparsınız? }\end{array}$ & 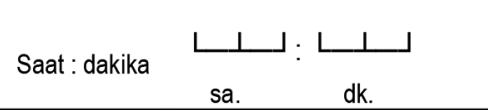 & $\begin{array}{l}\mathrm{P} 15 \\
(\mathrm{a}-\mathrm{b})\end{array}$ \\
\hline \multicolumn{4}{|c|}{ Sedanter Davranış } \\
\hline \multicolumn{4}{|c|}{$\begin{array}{l}\text { Aşağıdaki soru işte, evde, ulaşımda veya arkadaşlarla oturma ya da uzanma/yaslanma hakkındadır (masada oturma, arkadaşlarla oturma, } \\
\text { arabada, otobüste, trende seyahat etme, okuma, iskambil oynama veya televizyon izleme), fakat uyurken geçirilen zamanı dahil etmeyiniz. } \\
\text { [ÖRNEKLER EKLEYiNiz] }\end{array}$} \\
\hline 16 & $\begin{array}{l}\text { Sıradan bir günde oturarak ya da uzanarak/yaslanarak } \\
\text { genellikle ne kadar zaman geçirirsiniz? }\end{array}$ & Saat : dakika & $\begin{array}{l}\text { P16 } \\
(a-b)\end{array}$ \\
\hline
\end{tabular}

